\section{Effects of fire on structure, dynamics and regeneration of Quercus pyrenaica ecosystems.}

\author{
R. TÁRREGA * \\ E. LUIS-CALABUIG ${ }^{\star}$
}

SUMMARI - Post-fire regeneration is studied in forty-three communities of Quercus

pyrenaica in the province of Leon (Spain) burmed by surface fires from a

few weeks up to 60 years before the sampling, and is compared with four zones which have not been burned. A greater similarity in floristic composition is clearly to be seen in the different phases of one same community than between different communities with the same age of regeneration. The vegetation prior to the fire conditions, therefore, is to a great extent the one which will arise after it, the process constituting a compensatory autosuccession of the regression suffered.

Specific diversity increases in the first years, due mainly to an increase in species richness, showing later values more in accordance with each specific zone than to the time which has elapsed since the fire. All the communities studied are very heterogeneous, but the action of the fire can be seen as an additional generating factor of heterogeneity a few weeks after the burming. From all this, it can be deduced that these communities have been adapted to fire for a very long time and that most of the species have developed selective mechanisms to regenerate themselves quite effectively after the fires. KEYWORDS : post-fire regeneration, Quercus pyrenaica, autosuccession, diversity,
heterogeneity.

INTRODUCTION

Due to the increment of the great number of fires detected in the last few years, above all in the Mediterranean zones, the theme of forest fires has acquired a considerable importance nowadays. Nevertheless, this phenomenon, although it has increased in the last few decades, does not constitute something exceptional, rather it is a normal ecological factor, which has influenced the dynamics of the ecosystems of these zones for a very long time. Even before the appearance of man, fires were produced by lightning. Fire frequency increased later on by the action of farmers and shepherds. This has conditioned the development of a vegetation adapted to resist fire, and which usually resprouts immediately after the burning. The shrubby formations proper to the Mediterranean climates which are adapted to more or less periodical fires, are numerous, e.g. the Californian chaparral (BISWELL 1974, PARSONS 1976, KEELEY \& KEELEY 1981) and the maquia and garrigue in France (TRABAUD 1980, TRABAUD \& LEPART 1980), Israel (NAVEH 1974) and Greece (PAPANASTASIS 1977,1978 ).

The communities of Quercus pyrenaica discussed here cannot really be considered as bushes, but in most cases they cannot be considered as real woods either, because they are usually 'very much altered and the shrubby forms are predominant. In the zone studied, they are situated between the phytogeographic Mediterranean region and the Eurosiberian region (RIVAS et al. 1984). Their present state of degradation is due mostly to human activity, which includes the frequent fires, some of which must have been accidental, which would have extended from the neighbouring pasture grounds, and others ignited on purpose to make the area more practicable for cattle.

\footnotetext{
* Departamento de Ecologia, Facultad de Biologia, Universidad de Leon, 24071 LEON, Spain.
} 


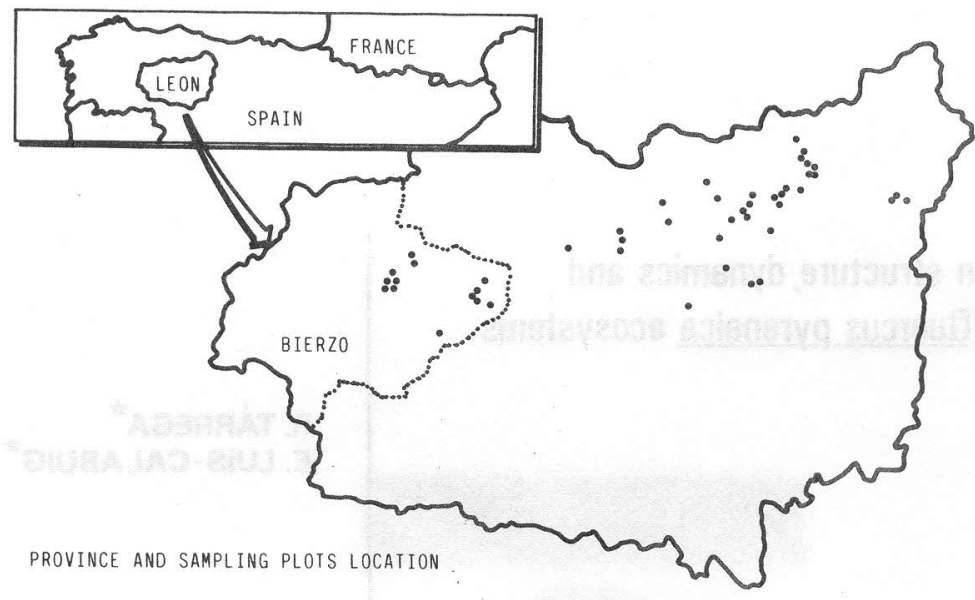

The main aim of the present study is centred, therefore, on the effects of fire on the structure, dynamics and regeneration of these ecosystems with the view of determining their degree of adaptation to the fires. The ideal in this type of study is to follow the evolution of the same communities through time, but as this is often impossible, it is necessary to revert to space-temporal extrapolations. Nevertheless, we have at our disposal the real temporal evolution of the vegetation, for three consecutive years for some zones, and also including amongst them a spectrum ranging from a month to eight years.

MATERIAL AND METHOD

\section{Description of the study zone}

A total of 47 communities were studied, all of them located in the province of Leon (Spain). Thirteen of them were situated in the region of E1 Bierzo, with a microclimate of 1 ts own, defined by a higher level of humidity and more temperate temperatures; they have been designated as $B A, B B, B C, B D, B E, B F, B G, B H, B I, B J, B K, B L$ and $B M$ respectively. The other 28, in the North-west of the province, are coded with the letters of the alphabet from A to $\mathrm{Z}$; 18 of these, the most recently burned or of a larger extension, were sampled for three consecutive years, placing before their code letter the numbers 1, 2 or 3, corresponding to the first, second or third sampling. In $1 A^{\prime}$ it was impossible to carry out inventories because no vegetation had sprouted. Those named as PA, PB and PC are those burned at an earlier date, though for the last two, part of them was burnt again recently, and both phases of each community have been sampled. The remaining three, NQ1, NQ2 and NQ3 belong to zones which, according to the information available, had never suffered a fire. The location of these zones can be seen in Fig. 1, and the UTM coordinates, the date of the fire and the sampling, as well as some general characteristics, in Table I. Zones BI, BJ and BK suffered two fires within the stated period.

All of them were surface fires allowing the survival of a great part of the trees.

\section{Sampling method}

In each zone, an average of ten inventories carried out at random were performed, with a square sampling unit of $50 \mathrm{~cm}$ a side. In each unit the data of the species present were collected, and their degree of importance was expressed in terms of cover average. The main aim of these inventories was the analysis of the herbaceous vegetation, theoretically the most sensitive to the perturbations and the post-fire dynamics unfortunately well known in these ecosystems. Nevertheless, the bushes of small size, even the sprouts of shrubby or arboreous specles included in the sampling units, were also registered. 
Table I - Definition of geographical characteristics and date of burning and sampling of the studied zones.

SITE UTM COORDINATES YEAR OF YEAR OF EXPOSURE ALTITUDE SLOPE

\begin{tabular}{|c|c|c|c|c|c|c|c|}
\hline BA & Sta. Ma, del Sil & $29 \mathrm{TQH} 057253$ & $1970-1982$ & 1982 & NW & $700-800$ & Quite pronounced \\
\hline BB & Toreno & 29TQH059294 & 1972 & 1982 & w & $700-800$ & Very pronounced \\
\hline BC & Toreno & 29TQH019352 & 1972 & 1982 & $\mathrm{NE}$ & $750-900$ & Very pronounced \\
\hline BD & Pardamaza & $29 \mathrm{TQH} 069389$ & 1973 & 1982 & SE & 1300 & Light \\
\hline $\mathrm{BE}$ & Pardamaza & $29 \mathrm{TQH} 086370$ & 1970 & 1982 & SW & $1300-1400$ & Variable \\
\hline BL & Valdelaloba & 29 TQHO21277 & - & 1982 & - & 700 & Imperceptible \\
\hline BM & Toreno & 29TQHO28335 & 1970 & 1982 & $\mathrm{~N}-\mathrm{NE}$ & $700-800$ & Very light \\
\hline BF & Almagarinos & $29 \mathrm{TQH} 254300$ & 1966 & 1982 & $\mathrm{~N}-\mathrm{NE}$ & $900-1000$ & Very pronounced \\
\hline BG & Almagarinos & $29 \mathrm{TQH} 251305$ & 1975 & 1982 & $\mathrm{~N}-\mathrm{NW}$ & $950-1000$ & Quite pronounced \\
\hline $\mathrm{BH}$ & Almagarinos & $29 \mathrm{TQH} 246306$ & 1966 & 1982 & E & 1000 & Variable \\
\hline BI & Sta. Marina & 29TQH156187 & 1973-1979 & 1982 & $\mathrm{~N}$ & $700-800$ & Quite pronounced \\
\hline BJ & Pobladura & $29 \mathrm{TQH} 280318$ & $1958-1980$ & 1982 & NW & 1000 & Quite pronounced \\
\hline BK & Tremor de Abajo & 29TQH252233 & $1963-1978$ & 1982 & NE & $900-1000$ & Very pronounced \\
\hline $\mathrm{v}$ & La Omanuela & 30TTN553404 & 1979? & 1982 & $\mathrm{E}$ & 1100 & Quite pronounced \\
\hline NQ1 & Quintanilla & $30 T T N 682401$ & - & 1982 & $\mathrm{~N}$ & $1000-1100$ & Quite pronounced \\
\hline $\mathrm{x}$ & Garano & 30TTN699425 & 1978 & $1981-83$ & S-SW & 1100 & Very light \\
\hline Y & Vega Caballeros & 30TTN686445 & $1980 ?$ & $1981-83$ & W-SW & $1000-1100$ & Variable \\
\hline$z$, & Carbajal & 30 TTN871240 & 1981 & $1981-83$ & W & 900 & Very light \\
\hline$A^{\prime}$ & Sta. Ma.del Monte & 30TTN996292 & 1981 & $1981-83$ & SE & 960 & Very light \\
\hline A & Sta. Ma.del Monte & 30TUN026306 & 1980? & $1981-83$ & - & 960 & Imperceptible \\
\hline$P$ & Ruiforco & 30TTN953347 & 1978 & $1981-83$ & W y N & $950-1050$ & Variable \\
\hline 0 & Pedun y Pardavé & 30 TTN 947413 & $1978 ?$ & $1981-83$ & E & 1000 & Variable \\
\hline $\mathrm{N}$ & La Valcueva & $30 T T N 977467$ & 1978 & $1981-83$ & NW & $1100-1200$ & Quite pronounced \\
\hline NQ2 & Vegaquemada & 30TUN083421 & - & 1982 & s & 950 & Very light \\
\hline LL & Campohermoso & 30TUN018469 & 1979 & $1981-83$ & $\mathrm{~N}$ y NW & 1100 & Quite pronounced \\
\hline M & Campohermoso & 30TUN017846 & $1978 \circ 79 ?$ & 1981 & s & 1200 & Quite pronounced \\
\hline B & Bonar & 30 TUN115520 & 1980 & $1981-83$ & $\mathrm{E}-\mathrm{NE}$ y $\mathrm{N}$ & $1000-1100$ & Very pronounced \\
\hline NQ3 & Oville & 30TUNO 95520 & - & 1982 & $\mathrm{~N}$ & $1100-1200$ & Very pronounced \\
\hline c & Bonar & 30TUN110525 & $1978 ?$ & 1981 & SE & $1000-1100$ & Very pronounced \\
\hline D & Valdecastillo & 30TUN113540 & $1978 ?$ & 1981 & SE & 1100 & Quite pronounced \\
\hline $\mathrm{E}$ & Vegamian & 30TUN155557 & 1981 & $1981-83$ & NW & $1300-1400$ & Very pronounced \\
\hline F & Lodares & 30TUN167576 & $1978 ?$ & $1981 .-83$ & $\mathrm{~s}$ & 1200 & Very pronounced \\
\hline G & Pallide & 30TUN176580 & $1978 ?$ & $1981-83$ & Shi & $1100-1200$ & Quite pronounced \\
\hline H & Pallide & 30TUN179576 & $1978 ?$ & 1981 & NW y W & $1150-1250$ & Quite pronounced \\
\hline I & Orones & 30TUN175588 & $1980 \circ 81 ?$ & 1981 & w & 1250 & Quite pronounced \\
\hline $\mathrm{J}^{\prime}$ & Orones & 30TUN173595 & $1980 ?$ & 1981 & SW & $1200-1300$ & Quite pronounced \\
\hline $\mathrm{J}$ & Orones & 30TUN173603 & $1979 \circ 80 ?$ & $1981-83$ & W y W-SW & 1400 & Quite pronounced \\
\hline Q & Cofinal & 30TUN127666 & $1978 \circ 79 ?$ & 1981 & W y SW & $1300-1400$ & Variable \\
\hline $\mathrm{K}$ & Valdepiélago & 30TUN038505 & 1979 & $1981-83$ & E-SE & $1100-1250$ & Quite pronounced \\
\hline L & Nocedo & 30TUN0 36535 & $1980 ?$ & $1981-83$ & s & $1300-1450$ & Quite pronounced \\
\hline R & Vegacervera & 30 TTN 937524 & $1979 ?$ & 1981 & $\mathrm{~s}$ & $1150-1200$ & Light \\
\hline s & Felmin & 30TTN925552 & $1979 ?$ & 1981 & $S-S E$ & $1100-1200$ & Quite pronounced \\
\hline $\mathrm{T}$ & Puente de Alba & $30 \mathrm{TTN} 244442$ & $1979 ?$ & $1981-83$ & $N$ y E & $1000-1] 00$ & Variable \\
\hline $\mathrm{U}$ & Buiza & $30 T T N 805521$ & 1975 & $1981-83$ & E-NE & $1200-1300$ & Variable \\
\hline PA & Prioro & 30TUN 386539 & $1920 ?$ & 1982 & s & $1200-1300$ & Very light \\
\hline PB & Prioro & 30TUN358501 & $1962-1.978$ & 1982 & $S$ y NE & 1200 & Variable \\
\hline PC & Prioro & 30 TUN 417514 & $1965-1978$ & 1982 & NW & $1250-1400$ & Very pronounced \\
\hline
\end{tabular}

\section{Statistic treatment}

Due to the enormous amount of data collected, a statistic analysis to quantify and thus clarify the information was considered necessary. For this, an average cover of the species in the total of the inventories belonging to each community and sampling is employed, except for those communities where we have no certainty about the year of the burning.

Three affinity analyses between the different groups of samplings are carried out: a temporal analysis, considering the samplings in order to their ages distinguishing between samplings with ages of post-fire regeneration ranging from one to three years; between samplings over three years after the fire; and a third analysis among communities located in E1 Bierzo, because of the peculiar characteristics of this region. For this, an index attributed to Steinhaus by MOTYKA et al. (1950), which is applied with quantitative variables, is used, and it is expressed with the formula:

$$
S_{\left(x_{1}, x_{2}\right)}=\frac{2 w}{A+B} 100
$$

where $w=$ summation of the lowest cover value of the species present in the two samplings

$$
\mathrm{x}_{1} \text { and } \mathrm{x}_{2} \text {. }
$$


$A=$ summation of all the cover values of all the species present in sampling $x_{1}$.

$B=$ summation of all the cover values of all the species present in sampling $x_{2}$.

The results obtained are grouped together by means of the UPGMA method (SOKAL \&

MICHENER 1958) and are represented graphically in form of dendrograms.

The specific diversity is also calculated by the information index of SHANNON-WEAVER

(1949):

$$
H^{\prime}=\sum_{i=1}^{s} P_{1} \log _{2} p_{i}
$$

where $p_{i}=$ probability of finding species 1 .

$s=n^{0}$ of species.

Their evolution over the course of time as well as their components, richness and uniformity are studied.

The heterogeneity of each sampling is also studied by means of a modified expression of the formula of MARGALEF (1972):

$$
\text { Het. }=H_{T}^{\prime}-\frac{\sum_{i=1}^{n} H^{\prime} \alpha_{1}}{n}
$$

where $\mathrm{H}^{\prime}{ }_{\mathrm{T}}=$ diversity of the sampling according to the Shannon-Weaver index.

$H_{\alpha}^{\prime} i=$ diversity of each inventory of that sampling.

$\mathrm{n}=$ number of inventories performed in that sampling.

\section{RESULTS AND DISCUSSION}

In the affinity analysis of the samplings out from one month to three years after

fire, we can see the biggest difference in the floristic composition of the other samplings compared with $1 \mathrm{E}$ and 12 , where there were only a few weeks of regeneration, where the soll without vegetation is predominant, and with only a few perennial species, which differ in both cases as these 2 samplings do not associate with each other. The predominance of the vivacious species (TARREGA 1986), with only three annual species out of the 16 registered, suggests, in both cases, that most of them resisted the fire fundamentally by means of underground organs, from which plants rapidly sprouted. This is a phenomenon quoted by numerous authors (DEBUSSCHE et al. 1980, TRABAUD 1980, CASAL et al. 1984).

The separation of the samplings belonging to zone $A^{\prime}$ can also be appreciated from the dendrogram, which can be explained by the great abundance of Cistus laurifolius and Ornithopus compressus in it, which practically do not appear in the others, as well as by the large predominance of annual species which penetrate from the neighbouring pasture grounds, due to the lesser density of trees in this community, and which conditions a quite different floristic composition (Fig. 1).

Taking into account the remaining areas, which have in common that small sprouts of oak trees are found in them, we can distinguish two sub-groups. The first one is characterized by the presence of Chamaespartium tridentatum, which does not appear in the areas which are part of the other sub-group. The great abundance of Melampyrum pratense also stands out, which conditions the union of $2 \mathrm{E}, 3 \mathrm{E}, 1 \mathrm{LL}$ and $2 \mathrm{LL}$. In the second group the biggest similitude appears between group $2 \mathrm{Z}$ and $3 z$, which are the only samplings in which Thapsia villosa is present. 


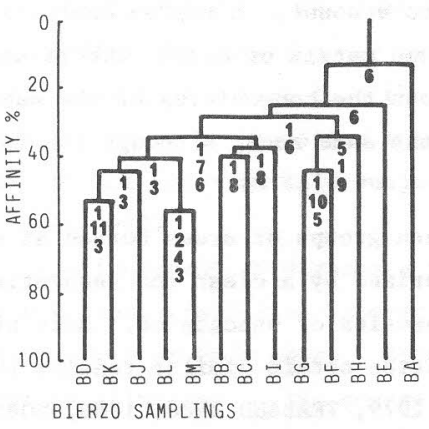

THE MOST IMPORTANT SPECIES AND theIR INFLUENCE IN THE AFFINITY LEVEL.

1. Quercus pyrenaica 16. Cytisus scoparius

2. Brachypodium pinnatum 17. Luzula lactea

3. Physospermum cornubiense 18. Asphodelus albus

4. Melampyrum pratense 19. Cistus laurifolius

5. Festuca rubra 20. Ornithopus compressus

6. Arenaria montana 21. Vicia sativa

7. Lithodora diffusa 22. Carex praecox

8. Anthoxanthum odorotum 23. Clinopodium vulgare

9. Stellaria holostea 24. Avenula marginata

10. Melittis melisophyllum 25. Agrostis capillaris

11. Pterium aquilinum 26. Andryala integrifolia

12. Silene nutans 27. Adenocarpus complicatus

13. Chamaespartium tridentatum 28. Deschampsia flexuosa

14. Thapsia villosa 29. Vaccinium myrtillus

15. Lotus corniculatus
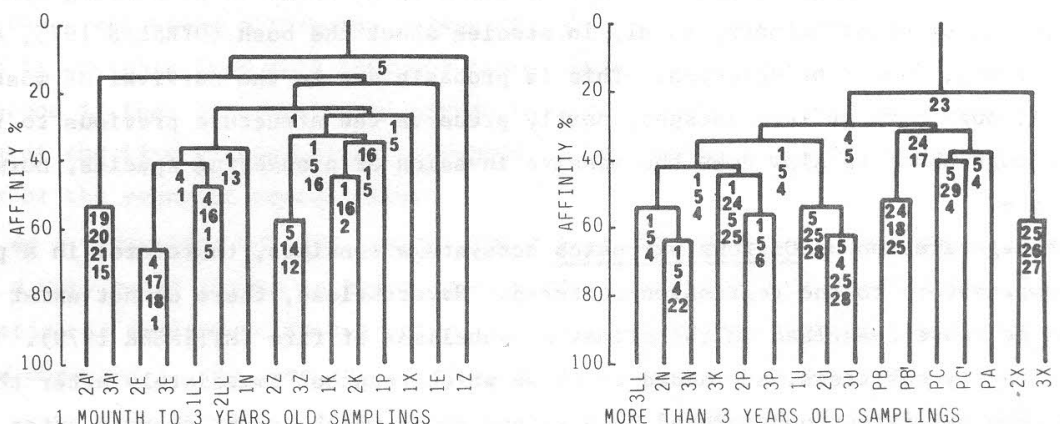

Fig. 1.- Affinity relations for three different analysis.

It can be appreciated that the association between the zones is not determined by the time that has elapsed since they suffered the fire, with the exception of the communities with only a few weeks of recovery which, for this reason, do not follow the same trend as the others. A preferential grouping can be detected in the other cases among the different samplings of a same area, which shows a greater resemblance among the different phases of a same community than among the samplings of the same age belonging to different zones.

In the dendrogram pertaining to the communities burnt at an earlier date (more than a three year post fire period) the connection between the samplings from a same zone is also apparent even where there are great differences in the age of regeneration, as in the case of PB and PC. The pair 2z-3z, differs from the others because it lacks Melampyrum pratense, a species highly abundant in the others. The influence of the geographic proximity in the associations can be observed, as in the group of areas located near the village of Prioro (PA, PB and PC) though this is not a general rule. The influence of many other factors which condition the floristic composition cannot be denied, the most important being connected to each specific area.

Similar results are obtained in the affinity analysis of the zones located in El Bierzo. The largest affinity group (BD, BK, BJ, BL and BM) is characterized by the presence of Physospermum cornubiense, a species which does not occur in the others. In the remaining groups the union is determined by the total of the species rather than by the exclusive apparition of one which makes them differ from the others. The association of the different zones in some cases is caused by the geographic proximity which conditions similar microclimatic and edaphic characteristics for vegetation, but in most cases it depends on the complex interaction of multiple factors, such as the orientation of the slope, the density and size of the trees, etc. It seems clear that the time elapsed since the attack of the fire is just one of the factors of this group. That it is not one of the most important factors is illustrated by the fact that no connection can be detected between the three areas which suffered a fire again more recently, (BI, BJ and BK) and the area which did not suffer the fire (BL) is not to be distinguished from the remaining ones (Fig. 1$)$.

Global analysis of all zones (those with an approximate date of burning as well) were carried out, determining the similitude in relation to the Euclidean distance and using a computer for that purpose. Because of the great magnitude of the species found in all zones (339) which exceeded the capacity of the computer, it was necessary to leave aside the species which were found 
in less than five samplings, out of the total of 80 taken into account. A factor analysis in the principal components was also performed, starting from the same matrix of data. The results obtained (TARREGA 1986) confirm the lack of association between the communities of the same age of regeneration, and a bigger resemblance between samplings of the same zone, although the latter is masked by the suppression of species.

The fact that there is no discrimination between groups of areas burned at similar dates shows clearly the lack of successional stages, characterized by a clear and sequential floristic relay such as the one described in the classical theories of succession. Most of the authors who study the post-fire regeneration of plant communities obtain similar results (METHVEN et al. 1975, PURDIE \& SLATYER 1976, SAUER 1977, OHMANN \& GRIGAL 1979, TRABAUD 1980, 1986, NOBLE 1981, etc.). The development of the vegetation after the fire is conditioned to a great extent by the floristic composition of the community prior to it. A phase of invasion of pioneering species, mostly annual, detected by other authors, mainly in studies about the bush (DYRNESS 1973, ANDERSON \& BAILEY 1979, CASAL 1984), cannot be detected. This is probably due to the survival of most of the oak trees which, although more or less damaged, partly preserve the structure previous to the fire, and usually give enough shade to slow down the massive invasion of pioneering species, normally of the heliophilous type.

The regeneration of Quercus pyrenaica ecosystems consists, therefore, in a process of autosuccession, compensatory to the regression suffered. Nevertheless, there do not exist cyclical changes of species as those described in the climax or subclimax of fire (MYTINGER 1979). To the surviving species, mostly oak trees, are added to those which resprout immediately after the burning, starting from persistant underground organs, and those which sprout shortly after springing from seeds which were already in the zone and resisted thanks to the bad diffusion of the heat in the soil, or due to seeds coming from the neighbouring communities.

This progressive incorporation of species conditions an increment of the diversity during the first two years (Fig. 2), although later on this tendency is not general in all the
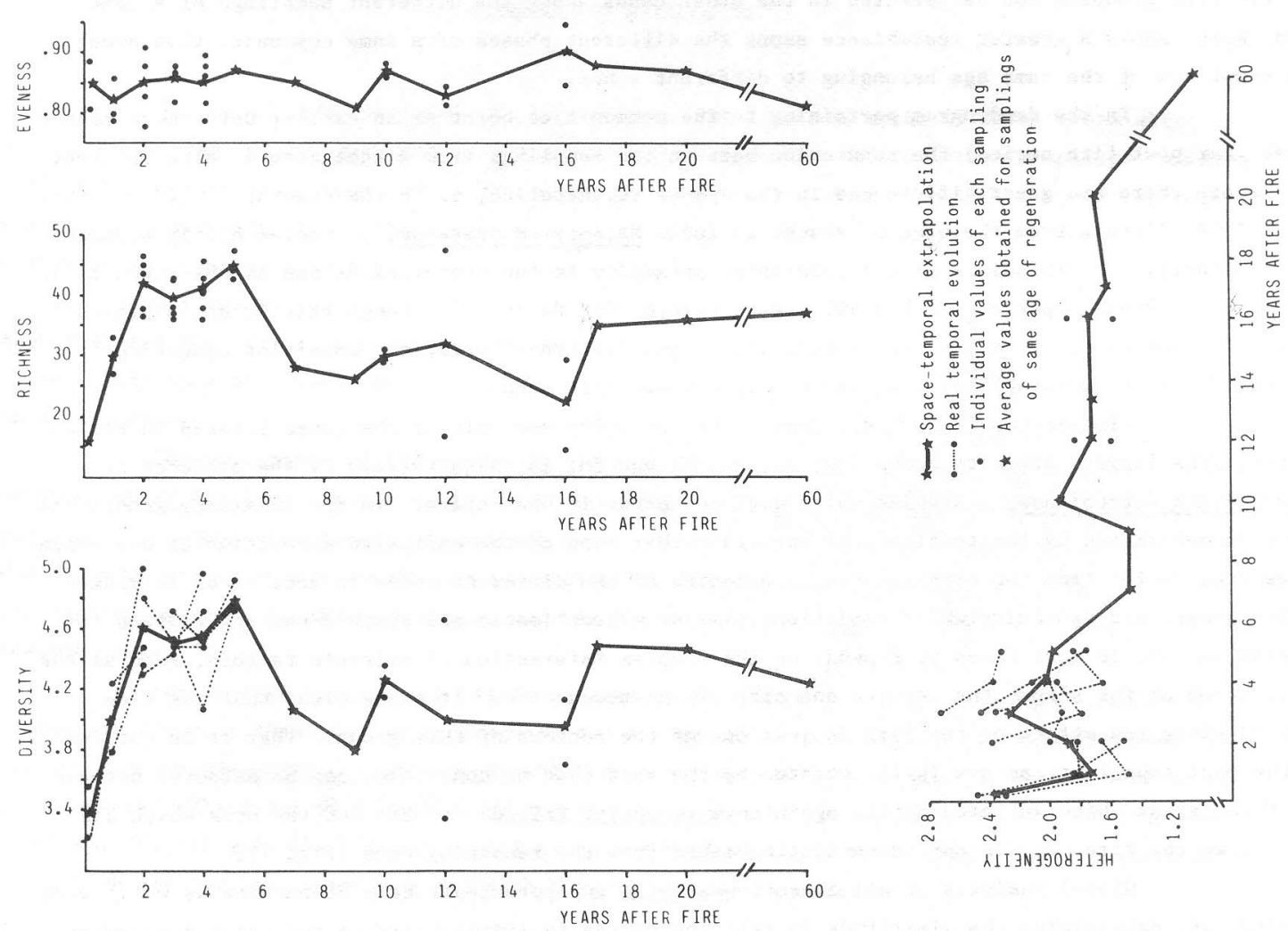

Fig. 2.- Structural parameters evolutions after fire. 
zones. If the average value of the diversities of the zones of the same age is taken into account, a stabilization during the period up to five years can be noted, showing thereafter an irregular evolution, partly due to the fact that there are less data available. The progressive increment of the diversity in the first years after the fire followed by a posterior descent or stabilization is evident in most of the works on this subject (BELL \& KOCH 1980, DEBUSSCHE et a1. 1980, TRABAUD \& LEPART 1980, CASAL 1982).

The increment of diversity is mostly due to the increment in the number of species (richness) as the great similarity between the 2 graphs shows, with a similar evolution. SHAFY \& YARRANTON (1973) agree on this point. Uniformity has a more irregular behaviour, although with very small irregular oscillations in the course of time.

As far as the evolution of heterogeneity is concerned, if the average values are taken into account, it can be observed that the highest heterogeneity belongs to the communities just burned, the graph being afterwards irregular, although with an overall tendency to decrease (Fig. 2). It is probable that this tendency cannot be generalized because the oscillations can be better understood if they are considered linked to the heterogeneity values of each specific area, independently of the time elapsed since it burned. What really seems to be meaningful is the high heterogeneity of the youngest communities.

Fire can act as a perturbing element, exercising a more intense effect in some plots than in others depending to a very small extent on the microclimatic and topographic conditions. This determines If the vegetation is influenced to a greater or lesser extent and enables sma11, almost intact, mosaics to be observed in the same zone, surrounded by areas completely burned.

Al1 the ecosystems studied show a great heterogeneity independently of their age of post-fire regeneration. Besides, they offer remarkable differences between each other, as can be verified by observing the deviation of some values from the average (for example, zones BE and BM, burnt twelve years before the study was carried out). Because of this, space-temporal extrapolations are not commendable in this type of community, and they must be only given an approximate value, backed by the temporal dynamics of the same communities.

CONCLUSION

The ecosystems of Quercus pyrenaica do generally recover well after the action of surface fires in a process of autosuccession which shows the presence of species adapted for a very long time to these perturbations. A progressive increment of the specific diversity of the herbaceous stratum up to two years after the burning can be observed. From that moment onwards it is difficult to detect structural differences caused by fire, and due to the survival of most of the oak trees, the passage of fire can only be recognized because of some burnt remains.

Nevertheless, it seems clear that the increment in the frequency of fires registered in the last few years constitutes an enormous factor of risk (TARREGA 1986). The fact that a system in a stage of recovery is again damaged after a very short time by a new fire, results in an increasingly greater degradation of the environment, which can lead to an irreversible alteration of the ecosystem.

REFERENCES

ANDERSON M.L. \& BAILEY A.W. (1979). Effect of fire on a Syphoricarpus occidentalis shrub community in Central Alberta. Can. J. Bot., 57 (24), 2819-2823.

BELL D.T. \& KOCH J.M. (1980). Post-fire succession in the northern jarrah forest of Western Australia. Aust. J.Ecol., 5 (1), 9-14.

BISWELL H.H. (1974). Effects of fire on chaparral. Fire and Ecosystems. T.T. Kozlowski \& C.E. Ahlgren, Acad. Press, New York, 321-364.

CASAL M. (1982). Sucesión secundaria en vegetación de matorral de Galicia tras dos tipos de perturbación: incendio y roza. Tesis doctoral, Univ. de Sevilla. 
CASAL M., BASANTA M., GARCIA NOVO, F. (1984). La regeneración de los montes incendiados en Galicia. Monogr. de la Univ, de Santiago de Compostela, 99 p.

DEBUSSCHE M., ESCARRE J., LEPART J. (1980). Changes in Mediterranean shrub communities with Cytisus purgans and Genista scorpius. Vegetatio, 43, 73-82.

DYRNESS C.T. (1973). Early stages of plant succession following logging and burning in the Western Cascades of Oregon. Ecology, 54, 57-69.

KEELEY J.E. \& KEELEY S.C. (1981). Post-fire regeneration of Southern California chaparral. Amer. J. Bot., 68 (4), 524-530.

MARGALEF R. (1972). El Ecosistema. Ecología marina, Dossat.

METHVEN I.R., VAN WAGNER C.E., STOCKS B.J. (1975). The vegetation on four burned areas in North-Western Ontario. Can. For. Serv., Pentawawa For. Exp. Stn. Chalk River, Ontario, Inf. Rep. PS-X-60.

MYTINGER L.L. (1979). A successional survey of the fire climax communities of Myakka River State Park. Fla. Sci., 42 (1)。

MOTYKA J., DOBRZANSKI B., ZAWADZKI S. (1950). Preliminary studies on meadows in the South-East of the province Lublin. Ann. Univ. Mariae Curie-Sklodowska Sect. E: Agricultura, 5, 367-447.

NAVEH 2. (1974). Effects of fire in the Mediterranean region. Fire and Ecosystems. T.T. Kozlowski \& C.E. Ahlgren. Acad. Press, New York, 401-434.

NOBLE I.R. (1981). Predicting successional change. Fire regimes and ecosystems properties. USDA For. Serv. Gen. Tech. Rep. W0-26, 278-300.

OHMANN L.F. \& GRIGAL D.F. (1979). Early revegetation and nutrient dynamics following the 1971 Little Sioux forest fire in Northeastern Minnesota. For. Sc. Monogr., 21.

PAPANASTASIS V.P. (1977). Fire ecology and management of phrygana communities in Greece. Environmental consequences of fire and fuel management in Mediterranean ecosystems. USDA For. Serv. Gen. Tech. Rep. W03, 476-482.

PAPANASTASIS V.P. (1978). Early succession after fire in a maquis-type brushland of N. Greece. The forest, 19-26.

PARSONS D.J. (1976). The role of fire in natural communities: An example from the Southern Sierra Nevada, California. Environ. Conserv., 3, 91-99.

PURDIE R.W., SLATYER R.O. (1976). Vegetation succession after fire in sclerophyll woodland communities in South-Eastern Australia. Aust. J. Ecol., 1 (4), 223-236.

RIVAS S., DIAZ T.E., FERNANDEZ J.A., LOIDI J., PENAS A. (1984). La vegetación de alta montaña cantábrica: Los Picos de Europa. Ed. leonesas, León, 295 p.

SAUER J.D. (1977). Fire history, environmental patterns, and species patterns in Sta. Monica mountain chaparral. Environmental consequences of fire and fuel management in Mediterranean ecosystems. USDA For. Serv. Gen. Tech. Rep. W03, 383-386.

SHAFI M.I. \& YARRANTON G.A. (1973). Diversity, floristic richness and species evenness during a secondary (post-fire) succession. Ecology, 54 (4), 897-902.

SHANNON C.E. \& WEAVER W. (1949). The mathematical theory of communication. Urbana I11. Univ. Illinois Press, $117 \mathrm{p}$.

SOKAL R.R. \& MICHENER C.D. (1958). A statistical method for evaluating systematic relationships. Univ. Kansas Sci. Bu11. 38, 1409-1438

TARREGA R. (1986). Regeneración post-fuego del estrato herbáceo en robledales de Quercus pyrenaica en la provincia de Leon. Tesis doctoral. Univ. de Leon.

TRABAUD L. (1980). Impact biologique et écologique des feux de végétation sur l'organisation, la structure et l'évolution de la végétation des zones de garrigues du Bas-Languedoc. Thèse de Doctorat d'Etat. Forêt Méditerranéenne.

TRABAUD L. (1986). Aspect floristique de la recolonisation des garrigues de Quercus coccifera et des forêts de Pinus halepensis après incendie en Bas-Languedoc (France). Bases écologiques per la gestió ambiental. Ed. Disputació de Barcelona, 13-16.

TRABAUD L. \& LEPART J. (1980). Diversity and stability in garrigue ecosystem after fire. Vegetatio, $43(1-2), 49-57$. 